\title{
How Proteins Catalyze Ligand Formation: Protein- Templated Fragment Ligation Employed in the Validation of Cancer Targets ${ }^{+}$
}

\author{
Jörg Rademann \\ Medicinal Chemistry, Institute of Pharmacy, Freie Universität Berlin, Königin-Luise-Str. 2+4, 14195 Berlin, \\ Germany; joerg.rademann@fu-berlin.de \\ + Presented at the 2nd Molecules Medicinal Chemistry Symposium (MMCS): Facing Novel Challenges in \\ Drug Discovery, Barcelona, Spain, 15-17 May 2019.
}

Published: 21 November 2019

Fragment-based drug discovery has been established as a powerful method for the assembly of optimized protein ligands. We employed protein-templated ligations, initially for the site-directed detection of low-affinity fragments and subsequently for the identification of potent fragment combinations that are useful as chemical tools [1-4].

Reversible and irreversible reactions have been employed for ligand construction. Here, we will reflect on the reaction scope of protein-catalyzed ligand formation and consider the thermodynamic and kinetic implications of the reactions. The approach will be demonstrated for the discovery of viral protease inhibitors. Orthosteric inhibitors of the oncogenic protein tyrosine phosphatase SHP2 have been provided and validated in cells and animal models as potent anticancer agents.

Finally, we will show that oncogenic transcription factor STAT5 is able to catalyze Mannich ligation reactions of fragments yielding inhibitors of leukemic cell proliferation. The $\mathrm{pH}$-dependency and protein-specificity of the protein-induced multicomponent reaction was studied and the ligands formed were validated by biophysical studies. They disrupt STAT5-DNA complexes and block phosphorylation of STAT5 and transcription by STAT5 in cells and in animal models inducing apoptosis specifically in STAT5-dependent cells.

\section{References}

1. Schmidt, M.F.; Isidro-Llobet, A.; Lisurek, M.; El-Dahshan, A.; Tan, J.; Hilgenfeld, R.; Rademann, J. Sensitized detection of inhibitory fragments and iterative development of non-peptidic protease inhibitors by Dynamic Ligation Screening. Angew. Chem. Int. Ed. 2008, 47, 3275-3278.

2. Becker, D.; Kaczmarska, Z.; Arkona, C.; Schulz, R.; Tauber, C.; Wolber, G.; Hilgenfeld, R.; Coll, M.; Rademann, J. Irreversible inhibitors of the $3 C$ protease of Coxsackie virus through templated assembly of protein-binding fragments. Nat. Commun. 2016, 7, 12761.

3. Jaegle, M.; Wong, E.L.; Tauber, C.; Nawrotzky, E.; Arkona, C.; Rademann, J. Protein-Templated Fragment Ligations: From Molecular Recognition to Drug Discovery. Angew. Chem. Int. Ed. 2017, 56, 7358-7378.

4. Wong, E.L.; Nawrotzky, E.; Arkona, C.; Kim, B.G.; Beligny, S.; Wang, X.; Wagner, S.; Lisurek, M.; Carstanjen, D.; Rademann, J. The transcription factor STAT5 catalyzes Mannich ligation reactions yielding inhibitors of leukemic cell proliferation. Nat. Commun. 2019, 10, 66.

(C) 2019 by the authors. Licensee MDPI, Basel, Switzerland. This article is an open access article distributed under the terms and conditions of the Creative Commons Attribution (CC BY) license (http://creativecommons.org/licenses/by/4.0/). 